\title{
PALKKATYÖ TYÖHÖNVALMENNUKSEN TAVOITTEENA KEHITYSVAMMAISILLA TYÖNHAKIJOILLA
}

\section{Tausta}

Kehitysvammaisille työnhakijoille tarjottavaa työhönvalmennusta halutaan suunnata kohti palkkatyötä ja niin sanottua Individual Placement and Support (IPS) -mallia (Becker Ct Drake, 1994). Työhönvalmennuksen IPS-malliin viitataan monesti myös näyttöön perustuvana tuetun työllistymisen mallina (ks. taulukko 1), jonka työllistymistulokset ovat tutkimuksissa toistuvasti ylittäneet muiden palvelumuotojen tuloksen (Bond 2004). Tutkimusnäyttö perustuu tosin lähinnä yhdysvaltalaisiin mielenterveyskuntoutujilla toteutettuihin vertailututkimuksiin, eikä vastaavia tuloksia välttämättä saavuteta kehitysvammaisten ihmisten työllistymisessä. Käytännössä IPS-mallia ei yleensä myöskään noudateta sellaisenaan tutkimusten ulkopuolella (Spelkavik \&t Evans 2007). Esimerkiksi työn etsintä aloitetaan usein hitaammin kuin IPS-mallissa esitetään. Lisäksi jonkinlaiset arvioivat ja valmentavat jaksot nähdään usein tarpeellisina. (Spelkavik \&t Evans 2007.) Näin on erityisesti kehitysvammaisten työnhakijoiden kohdalla, sillä heidän kanssaan on vaikeaa käyttää Tuetun työllistymisen mallin mukaisia asiakasprofiloinnin menetelmiä, kuten haastattelua, kyselyitä tai itsearviointeja (Walsh 2006). Tässä katsauksessa esitellään kehitysvammaisten työnhakijoiden yksilöarvioinnin näkökulmia palkkatyötä tavoittelevassa työhönvalmennuksessa.

\section{Kehitysvammaisten työnhakijoiden työhönvalmennus ja työmotivaation arviointi}

Nykyisellään kehitysvammaisille työnhakijoille on tarjolla työhönvalmennusta vaihtelevasti paikkakunnasta riippuen (Vesala ym. 2015). Myös sen sisällöt ja työelämätavoitteet voivat vaihdella palvelun tuottajasta riippuen. Kuntien järjestämä työhönvalmennus toteutuu useimmiten osana työtoimintojen ohjausta (Sosiaali- ja terveysministeriö 2014). Tällöin sen tavoitteeksi voidaan tapauskohtaisesti asettaa esimerkiksi pitkäjänteisyyden harjoitteleminen, ja asiakasta voidaan tukea palkkatyön sijasta myös kohti avotyötoimintaa. Kehitysvammaiset työnhakijat voivat periaatteessa hakeutua myös Kelan työhönvalmennukseen, jonka tavoitteena on aina palkkatyö ja jonka valintakriteerinäkin ovat asiakkaan mahdollisuudet yltää merkittäviin lisäansioihin. Tällaisen suhteellisen vaativana pidetyn työhönvalmennuksen on kuitenkin aiemmin todettu soveltuvan melko heikosti kehitysvammaisten henkilöiden tarpeisiin (Härkäpää ym. 2013).

Kehitysvammaiset ihmiset hakeutuvat työhönvalmennukseen monista eri syistä. Suuri osa tavoittelee palkkatöihin pääsyä, mutta toiveena voi olla esimerkiksi johonkin ammattialaan tutustuminen ja joskus pelkästään toimintakeskusten välttäminen. Usein jääkin sosiaalityöntekijän tehtäväksi arvioida, missä 
Taulukko 1. Keskeisiä IPS-mallin sisältöjä.

\begin{tabular}{|l|}
\hline Keskittyminen avoimiin työmarkkinoihin \\
\hline Palvelunkäyttäjiä ei valikoida heidän ennalta arvioidun "työllistettävyytensä" perusteella. \\
\hline $\begin{array}{l}\text { Työhönvalmennus toimii yhteistyössä lääkinnällisen kuntoutuksen kanssa siten, että työhönvalmentaja } \\
\text { toimii osana hoitotiimiä. }\end{array}$ \\
\hline Töiden etsintä aloitetaan nopeasti - neljän viikon sisällä palvelun aloittamisesta. \\
\hline Palvelu ja töiden etsintä suunnitellaan asiakkaan omien toiveiden perusteella. \\
\hline $\begin{array}{l}\text { Töiden etsinnässä huomioidaan asiakkaan tuen tarpeet ja työskennellään yhteistyössä työnantajien kanssa } \\
\text { ns. piilotyöpaikkojen löytämiseksi. }\end{array}$ \\
\hline Tukea tarjotaan sekä asiakkaalle että työnantajalle niin pitkään kuin on tarpeellista. \\
\hline Asiakkaalle ja työnantajalle tarjotaan asiantuntevaa tukea tarjolla olevien taloudellisten tukien hakemiseksi. \\
\hline
\end{tabular}

määrin kuhunkin tavoitteeseen voidaan kulloinkin panostaa. Työhönvalmennus on suhteellisen edullista palvelua, eikä asiakasvalikointiin siten kohdistu suuria taloudellisia paineita. Sen sijaan asiakkaiden tulee selvitä työskentelyssään melko itsenäisesti, eikä palvelu välttämättä sovellu esimerkiksi henkilöille, joilla on käytösongelmia.

Mikäli työhönvalmennus rajautuu jatkossa palkkatyön tavoitteluun, työnhakijan oman työelämämotivaation kartoittaminen nousee keskeiseksi haasteeksi palvelunohjauksessa. Kehitysvammaisten työnhakijoiden palkkatyömotivaation selvittäminen voi nimittäin olla huomattavan vaikeaa ilman omakohtaista kokeilemisen mahdollisuutta. Heillä ei yleensä ole tällaisten valintojen edellyttämiä käsityksiä työelämästä, työtehtävistä tai omista työtaidoista. Heidän työmotivaationsa saattaakin vaikuttaa häilyvältä ja lyhytjänteiseltä, mikäli sitä pyritään arvioimaan tavanomaisten haastattelun, kyselyiden tai itsearviointien avulla (Finlay \&t Lyons 2001; Timmons ym. 2011). Tällöin vastaukset voivat heijastella esimerkiksi oman ikäluokan kulloisiakin toiveammatteja. Kehitysvammaisille suunnattuja työmotivaation kartoittamisen menetelmiä on ylipäätään tarjolla hyvin vähän (esim. Reading-free Vocational Interest Inventory 2, ks. Becker 2000), eivätkä ne kuvaa valittavana olevia työelämäpolkuja riittävän monipuolisesti ja ymmärrettävästi tämän kohderyhmän tarpeisiin.

Palkkatyötä koskevan motivaation kartoittaminen edellyttänee siis jatkossa jonkinlaista työhönvalmennusta edeltävää työelämäjak- soa, jotta kehitysvammaiset työnhakijat pystyvät mieltämään, millaisia työelämävaihtoehtoja he ovat itselleen valitsemassa. Aitojen, tietoon perustuvien elämänvalintojen mahdollistamiseksi tällaisessa esivalmennuksessa voidaan hyödyntää niin sanotun "yksilökeskeisen elämänsuunnittelun" menetelmiä (Mansell \&t Beadle-Brown 2004). Nämä menetelmät pyrkivät pohjustamaan päätöksentekoa kuvaamalla muun muassa taustatietoja, tukiverkostoja ja elämäntilanteita visuaalisten mallien ja elämänpolkukarttojen avulla. Tällainen lähestymistapa voi olla erityisen tarpeellinen silloin, kun työllistymispyrkimykset ajoittuvat samanaikaisesti muiden kuormittavien elämäntavoitteiden kanssa. Lisäksi työnhakijan yleisempää muutosvalmiutta voidaan pyrkiä kartoittamaan selvittämällä hänen tietämystään, asennoitumistaan ja henkistä kypsyyttään suhteessa tavoitteisiin. Mukana voi olla esimerkiksi kysymyksiä muutoksen tarpeesta, saatavilla olevasta tuesta sekä siitä, mitä henkilö on jo itse tehnyt tavoitteensa saavuttamiseksi.

\section{Taustatiedot ja tietojen vaihto}

Kehitysvammaisten ihmisten työhönvalmennus aloitetaan nykyään usein hyvin vähäisillä taustatiedoilla. Siinä tavoitellaan monesti myös itsenäistymis- ja irtautumiskehityksen tukemista, mistä syystä lähiomaisia ei välttämättä haluta käyttää taustatietojen antajina. Tässä työhön tukeminen poikkeaa huomattavasti terveydenhuollosta, jossa lähiomaisia 
pidetään välttämättöminäkin tietolähteinä arjen toimintakyvyn ja taitojen kartoittamisessa. Läheiskyselyillä voidaan saavuttaa hyödyllisiä tietoja esimerkiksi kommunikaatiokeinoista, mahdollisesta poikkeavasta käyttäytymisestä tai keinoista rauhoittua ongelmatilanteissa. Näiden lisäksi läheisiltä voitaisiin kerätä listoja niistä askareista ja työtehtävistä, joista työnhakija on aiemmin kyennyt suoriutumaan itsenäisesti. Joskus läheiset saattavat nähdä työllistymistavoitteen kilpailevan muiden samanaikaisten elämäntavoitteiden kanssa. Tällöin muista tavoitteista saattaa muodostua eräänlaisia "työllistymisvalmiuden" kriteereitä, jotka läheisten mielestä tulisi saavuttaa ennen töihin pyrkimistä. Näissä tilanteissa työnhakijan voi olla vaikeaa pitää kiinni omista tavoitteistaan.

Oppilaitokset eivät yleensä ota kantaa oppilaidensa edellytyksiin hyötyä työhönvalmennuksesta. Lisäksi mukautettuja opintotodistuksia on kritisoitu siitä, että ne eivät välitä luotettavaa tietoa varsinaisista työtaidoista (Ala-Kauhaluoma \&t Härkäpää 2006). Työhönvalmennuksen kannalta keskeisiksi taustatiedoiksi ovatkin osoittautuneet kuvaukset opiskelijan konkreettisesta osaamisesta ja itsenäisestä työsuoriutumisesta esimerkiksi työharjoittelujaksoilla. Tällaiset kirjaukset voivat kuitenkin olla hyvin vaihtelevia sekä työnantajasta riippuvaisia, ja niitä tulisi edelleen kehittää myös työhönvalmennuksen tarpeisiin.

IPS-mallista poiketen kehitysvammaisten työnhakijoiden työhönvalmennus ei yleensä toimi kiinteässä yhteistyössä mielenterveyskuntoutuksen tai muunkaan lääkinnällisen kuntoutuksen kanssa. Usein tiedonkulku on vähäistä myös asumispalvelun kanssa. Näistä syistä kulloisiakin kuormitustekijöitä ei aina pystytä ennakoimaan riittävästi. Toisaalta muut palvelut eivät pysty tukemaan työhönvalmennusta tehokkaasti esimerkiksi stressinhallintaa harjoittamalla.

\section{Osaamisen ja työsuoriutumisen arviointi}

IPS-mallissa asiakkaalle luodaan positiivinen, työnhakua tukeva asiakasprofiili, joka välttää ennakkoluuloista suhtautumista asiakkaan mahdollisuuksiin. Tämä asiakasprofiili luodaan yleensä lähinnä haastattelemalla (ks. esim. European Union of Supported Employment Toolkit) selvittäen työnhakijan tavoitteita ja konkreettista osaamista. Samalla pyritään yhdessä sopimaan siitä, mitä informaatiota työnhaussa pidetään relevanttina ja miten tuen tarpeista kerrotaan työnantajalle. Kehitysvammaisten työnhakijoiden kanssa näiden asioiden läpikäyminen kestää tavallista pidempään. Valmiit haastattelu- tai itsearviointimenetelmät (esim. Melba, ks. Föhres ym. 2004; WORQ, ks. Finger ym. 2014) eivät yleensä sovellu heille, ehkä joitain erikseen suunnattuja haastattelumenetelmiä lukuun ottamatta. Heillä työtaitojen kartoituksessa onkin tapana käyttää apuna muun muassa yksinkertaisia työtaitojen tarkistuslistoja. Näistä valtaosa on työhönvalmentajien itse laatimia, eikä asiakasprofilointiin ole löydetty yhtenäisiä käytäntöjä. Eräänkin kaupungin työhönvalmennuksessa laskettiin olevan käytössä yli 70 erilaista arviointimenetelmää.

IPS-mallin mukaan työhönvalmennuspalvelua ei tulisi rajoittaa työnhakijoiden taitojen perusteella. Lyhytaikaisia harjoittelujaksoja voidaan käyttää lähinnä työtaitojen ja tuen tarpeen arviointiin (European Union of Supported Employment Toolkit). Käytännössä tällaisista harjoittelujaksoista on kuitenkin muodostunut tarpeelliseksi koettu keino ohjata kehitysvammaisten asiakkaiden pääsyä varsinaiseen työhönvalmennukseen. Työn ohessa tapahtuvan havainnoinnin ajatellaan tuovan luotettavaa tietoa siitä, miten työnhakija tosiasiassa toimii ja miten hän kykenee suoriutumaan työnsä vaatimuksista. Lisäksi havainnointi voi tuoda tietoa tuen tarpeista sekä tavoista oppia uusia asioita. Kehitysvammaisten työntekijöiden toimintakyky voi riippua huomattavan paljon kulloisestakin fyysisestä ja sosiaalisesta ympäristöstä.

Joissain maissa (esimerkiksi Hollannissa ja osissa Saksaa) työhönvalmennuspalveluihin voidaan ohjautua myös yksilöarvioinnin ja testauksen pohjalta. Tällöin työskentelyn tuottavuutta voidaan arvioida esimerkiksi kokoonpanotyöhön suunniteltujen mittaus- 
menetelmien avulla (Methods-time measurement). Testauksessa voidaan puolestaan hyödyntää joko standardoituja työnäytteitä (mm. Valpar Component Work Samples, ks. esim. Jackson ym. 2004) tai varsinaisia testitehtäviä. Testit voivat liittyä tiettyihin ammatteihin esimerkiksi työkalujen käytön kautta (HandTool Dexterity Test, ks. Bennett 1965), jolloin saatavilla voi olla ammattialakohtaisia normeja. Kuitenkin arvioinnissa käytetään myös palveluntuottajien itse määrittämiä raja-arvoja. Tällaiseen arviointiin käytettäviä teollisuuspsykologian testistöjä pidetään yleisesti melko vanhanaikaisina (esim. Purdue Peg Board, ks. Tiffın \&t Asher 1948; Ruward-testi, ks. Weinert \& Wehner 1981), vaikka niitä edelleen hyödynnetään myös oppilaitosten pääsykokeissa ja EU:n työllisyysprojekteissa. Työllistymismahdollisuuksien kannalta on tärkeämpää selvittää, pystyykö henkilö suoriutumaan joistain tehtävistä niille asetettujen vaatimusten puitteissa, kuin arvioida hänen suoriutumistaan suhteessa muihin. Siksi suorituskriteereihin perustuvaa testausta pidetään tuetun työllistymisen kannalta relevantimpana ja hyväksyttävämpänä kuin normitietoihin nojaavaa testausta. Tällöinkin on tärkeää varmistua siitä, että suorituskriteerit todella heijastavat joitain työn kannalta keskeisiä vaatimuksia. Esimerkiksi pelkkä hitaus ei yleensä ole ehdoton työllistymisen este, ja hitautta kompensoimaan on yleensä saatavilla palkkatukea.

\section{Työn vaativuuden arviointi ja työn yhteensovittaminen}

Työpaikan löydyttyä työhön tukemisen prosessissa edetään työn vaatimusten arviointiin ennen työn tai työkokeilun aloittamista. Tämä toteutetaan yleensä haastattelemalla työnantajan edustajaa. Lisäksi työympäristöä ja työn tekemistä voidaan havainnoida, ja työhönvalmentaja voi myös itse kokeilla työn tekemistä. Näiden tietojen pohjalta työhönvalmentaja luo kuvauksen työn eri osatehtävistä. Yksinkertaisimmillaan kuvaus muistuttaa laajennettua tavallista tehtävänkuvausta.

Työn vaativuuden arvioinnissa voidaan käyttää apuna myös arviointimenetelmiä, joiden perusteella työn vaatimukset pyritään purkamaan tiettyihin osatekijöihin (esim. Melba ja keskeneräiseksi jäänyt EU-hanke UEmploy, ks. UEmploy European Report). Tällaiset menetelmät voivat olla erittäin aikaa vieviä, eivätkä ne välttämättä huomioi nykyaikaisten työtehtävien vaatimuksia. Esimerkiksi Melbaarviointimenetelmän on tarkoitus parantaa kommunikaatiota eri tahojen (työhönvalmentajan, työntekijän, työnantajan sekä palvelun tilaajan) välillä, mutta sen sisältämillä termeillä on selvästi arkikielestä poikkeavia merkityksiä. Tästä syystä sen käyttäminen edellyttää kouluttautunutta työhönvalmentajaa, joka toimii tulkkina eri osapuolten ja Melban välillä. Melbasta löytyy vastaava vaatimusasteikko myös työntekijän työsuoriutumisen erittelyyn. Siten molempien asteikkojen vertaaminen mahdollistaa työn ja työntekijän yhteensovittamisen. Kehitysvammaisten työntekijöiden työsuoriutumista ei voida kuitenkaan arvioida pelkkään haastatteluun perustuen, vaan se tulisi tehdä ensisijassa havainnoimalla - mieluiten useiden päivien aikana. Muun muassa näistä syistä Melban käyttö ei olekaan vakiintunut heidän työsuoriutumisensa arvioinnin välineeksi.

Palkkatyösuhteeseen tähdättäessä työsuoriutumiselle tulisi ihannetilanteessa asettaa jo ennalta jonkinlaiset tuottavuustavoitteet. Tämä selkiyttäisi työkokeilujen järjestämistä, kun työssä suoriutumista voitaisiin alusta pitäen verrata tiettyyn tavoitetasoon. Etenkään kehitysvammaisten työntekijöiden kohdalla näin ei kuitenkaan yleensä tapah$\mathrm{du}$, vaan suoriutumista arvioidaan epämääräisemmin ja yleensä vasta työelämäjakson päättyessä. Jakson aikana työnantajilta saatava palaute on usein hyvin niukkaa tai suoriutumisen hyviä puolia painottavaa. Kriittisempi palaute saattaa tulla esiin vasta jakson päättyessä, kun keskustellaan mahdollisen työsuhteen muodostamisesta. Työelämäjaksojen arvioinnissa käytetään monesti erilaisia palautelomakkeita, joissa arvioidaan etenkin yleistä työkäyttäytymistä. Työsuoriutumista ei yleensä verrata mihinkään ulkopuolisiin kriteereihin, vaan arviota voidaan pyytää esimerkiksi asteikolla 1-5. Tämä vaikeuttaa asiakkaan ko- 
konaistilanteen hahmottamista, sillä palautteen antajilla on taipumus skaalata asteikkoa kohteesta riippuen. Objektiivisempi kuva työnhakijan työsuoriutumisesta olisi kuitenkin tarpeen työhönvalmennuksen jatkon suunnittelemiseksi. Yksi esimerkki tällaisesta arviointimenetelmästä on Taidoista työpoluiksi -projektissa (RAY 2013-2017) luotu Työsuoriutumisprofiili (www.taidoistatyopoluiksi.fi). Siinä työnantajaa pyydetään vertaamaan työsuoriutumista hänen palkkatyölle asettamiinsa vähimmäisvaatimuksiin. Pidemmällä seurantaajalla Työsuoriutumisprofiilia voi käyttää myös erilaisten työtehtävien soveltuvuuden vertailuun sekä tarvittavan tuen määrän arviointiin.

\section{Työhönvalmennuksen tulokset ja vaikuttavuus}

Osatyökykyisten työhönvalmennukselle ei ole Euroopassa yleensä asetettu tiettyjä työllistymistavoitteita (Spjelkavik \& Evans 2007). Sen sijaan palvelun tuloksellisuuden seurannassa on käytetty esimerkiksi elämänlaadun arvioinnin menetelmiä (Kelan palveluissa WHOQOLBREF) tai palveluntuottajan itse laatimia toimintakyvyn arvioinnin menetelmiä, kuten The Samhall-Method (https://samhall.se/). Palvelunkäyttäjien omien tavoitteiden toteutumista on Suomessa seurattu lähinnä Kelan työhönvalmennuksessa (GAS-menetelmällä). Projektien ja muiden interventioiden vaikuttavuuden arviointiin on kehitteillä yksilötason muutoksia kartoittava Kykyviisari (https://www. ttl.fi/tutkimushanke/kykyviisari-arvioi-tyotoimintakykysi/). Kaikkien tällaisten yksilötason vaikutusten seuraaminen perustuu asiakkaiden tekemiin itsearviointeihin, ja niiden soveltaminen kehitysvammaisille työnhakijoille vaatii erityistä perehtyneisyyttä.

Työnhakijan kognition ja yleisen toimintakyvyn tiedetään ennustavan työhönvalmennuksen tuloksellisuutta sekä vaikuttavan tarvittavaan tuen määrään työhönvalmennuksessa (ks. esim. Su ym. 2008). Tällaisten tietojen keräämistä on pidetty tuetun työllistymisen filosofian vastaisena, mutta palveluiden kilpailutus tulee jatkossa lisäämään tarvetta toimintakykytiedon keräämiseen. Työhön- valmennus tulee mitoittaa asiakkaiden tarpeen perusteella ja sen tulosten arviointi tulee suhteuttaa käyttäjien toimintakykyyn. Myös palvelunkäyttäjät itse tarvitsevat tietoa palveluiden tuloksellisuudesta valintojensa perusteeksi.

\section{Lopuksi}

Kehitysvammaisille työnhakijoille tarjotaan siis nykyisellään melko avointa, yksilövalmennukseen keskittyvää työhönvalmennusta, jossa ei aina tavoitella varsinaista työllistymistä. Palkkatyötavoitteen myötä työelämätavoitteiden kirkastaminen ja valintojen tekeminen tulevat nousemaan entistä keskeisemmäksi osaksi työhönvalmennusprosessia. Tällöin työelämäjaksojen tavoitteita voidaan terävöittää. Kun työkokeilujen mittapuuksi otetaan alusta alkaen palkkatyön vaatimukset, tarvittavat mukautukset ja uudelleenjärjestelyt voidaan todeta nopeasti jo työkokeilun aikana. Haasteellisissa tilanteissa työkäyttäytymistä voidaan arvioida esimerkiksi videointien avulla. Joskus voi olla tarpeen palata myös työtaitojen harjoitteluun. Tiukasti katsoen tällainen palvelu ei enää kuuluisi varsinaiseen työhönvalmennukseen vaan johonkin sitä edeltävään mutta työelämään tähtäävään palveluun. Työhön tukemisen kokonaisuutta ajatellen onkin hyvä muistaa, että kokonaisten työnkuvien harjoittelu vie kehitysvammaisilla työntekijöillä monesti vähintään useita kuukausia.

Tulosten merkitys: Katsauksen sisältöjä voidaan käyttää kehitysvammaisten ihmisten työllistymistä tukevien palveluiden suunnittelussa. Esiteltäviä arvioinnin näkökulmia voidaan hyödyntää sekä palvelunohjauksessa että käytännön työhönvalmennuksessa.

Avainsanat: tuettu työllistyminen, työllistymisedellytysten arviointi, työhönvalmennus

Ville Villberg, PsM, psykologi, erityisasiantuntija, Taidoista työpoluiksi -projekti, Rinnekoti-Säätiö 


\section{Lähteet}

Ala-Kauhaluoma M, Härkäpää K (2006) Yksityinen palvelusektori heikossa työmarkkina-asemassa olevien työllistäjänä. Työpoliittinen tutkimus 312, Työministeriö, Helsinki.

Becker MDR, Drake RE (1994) Individual placement and support: A community mental health center approach to vocational rehabilitation. Community mental health journal 30, 2, 193-206.

Becker RL (2000) Reading-free Vocational Interest Inventory 2: Manual. Elbern Publications.

Bennett GK (1965) Hand-tool dexterity test. Psychological Corporation.

Bond GR (2004) Supported employment: evidence for an evidence-based practice. Psychiatric rehabilitation journal 27, 4, 345.

European Union of Supported Employment Toolkit. Education and Culture DG. Lifelong Learning Programme. http://www.euse.org/content/supported-employment-toolkit/EUSE-Toolkit-2010. pdf (haettu 11.1.2017).

Finger ME, Escorpizo R, Bostan,C, De Bie R (2014) Work Rehabilitation Questionnaire (WORQ): development and preliminary psychometric evidence of an ICF-based questionnaire for vocational rehabilitation. Journal of occupational rehabilitation $24,3,498-510$.

Finlay WM, Lyons E (2001) Methodological issues in interviewing and using self-report questionnaires with people with mental retardation. Psychological assessment 13, 3, 319.

Föhres F, Kleffmann A, Sturz A, Weinmann S (2004) Käsikirjat I, II ja III Melban käyttö,

6. uusittu painos. Durkhaus Kay GmbH, Lich Saksa. Suomennos Vammaisten lasten ja nuorten tukisäätiö, 2004.

Härkäpää K, Harkko J, Lehikoinen T (2013) Työhönvalmennus ja sen kehittämistarpeet. Sosiaali- ja terveysturvan tutkimuksia 128. Kelan tutkimusosasto, Helsinki.

Jackson M, Harkess J, Ellis J (2004) Reporting patients' work abilities: how the use of standardised work assessments improved clinical practice in Fife. The British Journal of Occupational Therapy 67, 3, 129-132.

Mansell J, Beadle-Brown J (2004) Person-centred planning or person-centred action? Policy and practice in intellectual disability services. Journal of Applied Research in Intellectual Disabilities 17, 1, 1-9.

Sosiaali- ja terveysministeriö (2014) Sosiaalihuollon työelämäosallisuutta tukevan lainsäädännön ja palvelujärjestelmän uudistamistarpeita arvioivan työryhmän loppuraportti. STM:n raportteja ja muistioita 2014:32.

Spjelkavik Ø, Evans MJ (2007) Impression of supported employment. A study of some European Supported Employment Services and their activities. Oslo: Work Research Institute.

Su CY, Lin YH, Wu YY, Chen CC (2008) The role of cognition and adaptive behavior in employment of people with mental retardation. Research in developmental disabilities 29, 1, 83-95.

Tiffin J, Asher EJ (1948) The Purdue Pegboard: norms and studies of reliability and validity. Journal of applied psychology 32, 3, 234.

Timmons JC, Hall AC, Bose J, Wolfe A, Winsor J (2011) Choosing employment: Factors that impact employment decisions for individuals with intellectual disability. Intellectual and developmental disabilities 49, 4, 285-299.

UEmploy European Report. European Contexts for Vocational Integration: Disability and

Employment. Saatavilla: http://www.eden-online.org/ nap_elgg/mod/file/download.php?file_guid=2734

Vesala HT, Klem S, Ahlstén M (2015) Kehitysvammaisten ihmisten työllisyystilanne 2013-2014. Helsinki: Kehitysvammaliitto.

Walsh PN (2006) Assessment and employment of people with intellectual disabilities. Assessing Adults with Intellectual Disabilities: A Service Providers' Guide, 138-151.

Weinert C, Wehner T (1981) Struktur-und dimensionsanalytische Betrachtungen des psychomotorischen Inventars von "Ruward": Untersucht an vier Gruppen dysmeler Jugendlicher und einer Kontrollgruppe. Diagnostica. 